Terbit online pada laman web jurnal : http://teknosi.fti.unand.ac.id/

Jurnal Nasional Teknologi dan Sistem Informasi

| ISSN (Print) 2460-3465 |ISSN (Online) 2476-8812|

Artikel Penelitian

\title{
Kontribusi Ekspektasi Kinerja, Usaha, Faktor Sosial dan Fasilitas Terhadap Sikap Operator Sistem Informasi
}

\author{
Krismadinata ${ }^{a}$,Yezi Arnovia ${ }^{b}$, Syahril $^{c}$, Yahfizham $^{d}$ \\ ${ }^{a, c, d}$ Fakultas Teknik, Universitas Negeri Padang, Jl. Prof. Dr. Hamka.Kampus UNP Air Tawar Padang 2517, Indonesia \\ ${ }^{b}$ Aparatur Sipil Negara Dinas Perdagangan, Koperasi dan UKM Pemerintah Kota Solok Propinsi Sumatera Barat Indonesia
}

\begin{tabular}{|c|}
\hline INFORMASI ARTIKEL \\
\hline $\begin{array}{l}\text { Sejarah Artikel: } \\
\text { Diterima Redaksi: } 05 \text { Februari } 2018 \\
\text { Revisi Akhir: } 28 \text { April } 2018 \\
\text { Diterbitkan Online: } 01 \text { Mei } 2018\end{array}$ \\
\hline KATA KUNCI \\
\hline $\begin{array}{l}\text { Variabel Kinerja dan Usaha, } \\
\text { Variabel Sosial dan Kondisi Fasilitas, } \\
\text { Sikap Operator Sistem Informasi }\end{array}$ \\
\hline KORESPONDENSI \\
\hline $\begin{array}{l}\text { Telepon: +62 (0751) } 7055644 \\
\text { E-mail: krisma@ft.unp.ac.id }\end{array}$ \\
\hline
\end{tabular}

\section{PENDAHULUAN}

Melesatnya teknologi informasi dan komunikasi telah membuat cara kerja seseorang telah berubah. Keberfungsian yang baik dari laju teknologi informasi dan komunikasi tersebut bagi orang dewasa dituntut agar mampu bertahan dan senantiasa senang untuk terus belajar. Meskipun begitu, segelintir orang dan juga lembaga kurang tanggap pada pergeseran kebiasaan, kebutuhan, bahkan budaya.

Banyaknya kendala yang terjadi ketika pekerjaan sedang dilakukan dengan inovasi, seperti teknologi informasi menjadi alasan yang kuat untuk mengabaikannya [1]. Penelitian terkait perilaku seseorang terhadap penggunaan teknologi informasi seperti mobile commerce dari aspek kepercayaan dan resiko penerapannya telah dilakukan [2]. Penggunaan dari teknologi komunikasi dengan segudang manfaatnya, tidak serta merta menjadikan institusi sukses dalam penerapannya. Terdapat banyak proyek dalam upaya perubahan sistem telah mengalami kegagalan [3]. Perilaku pemakai dalam hal adopsi sistem baru yang telah berjalan, dapat diobservasi dari sikap dan dapat diketahui dari persepsi mereka terhadap teknologi tersebut [4].

Perubahan cara kerja dari sistem manual menjadi sistem yang berbasis pada teknologi informasi [5]membuat para pengguna tidak mudah melakukan koreksi jika terjadi https://doi.org/10.25077/ TEKNOSI.v4i1.2018.044-052 kesalahan[6]. Server sering error/down pada saat banyak terjadi transaksi atau pada saat jam sibuk (jam kerja) [7]. Lamanya penanganan permasalahan yang timbul dari sistem merupakan permasalahan lain yang dihadapi pengguna aplikasi.

Dari beberapa keluhan akibat permasalahan yang muncul, diduga disebabkan oleh penerapan sistem informasi berbantuan komputer kurang sesuai dengan harapan/ekspektasi pengguna [8]. Pengguna (user) merupakan unsur utama yang menentukan keberhasilan suatu sistem [9]

Walaupun begitu, inovasi teknologi baru akan mampu memberikan profit bagi suatu organisasi. Adanya kegagalan memberlakukan hal-hal baru pada pekerjaan terjadi disebabkan oleh karena minimnya aspek penguasaan teknologi sipengguna. Keberhasilan dan ketidaksuksesan penerapan sistem sangat bergantung pada manusianya

Suatu keberhasilan implementasi sistem informasi, tidak hanya ditentukan oleh penguasaan teknis saja namun banyak penelitian yang menunjukkan bahwa faktor sikap individu pengguna sistem sangat menentukan kesuksesan implementasi Adopsi dan penggunaan sistem informasi yang rendah oleh user merupakan suatu hambatan yang besar dalam kesuksesan implementasi sistem informasi pada organisasi. Penolakan hati, sebagai contohnya adalah niat seseorang dalam bekerja dengan sesuatu hal yang baru, juga berpengaruh terhadap sikap [10-18]. 
Mengungkapkan dan memahami keberfungsian dari inovasi teknologi, seperti teknlogi informasi adalah dengan mengerti variabel-variabel dominan seperti minat, usia dan pengalaman telah banyak dikembangkan oleh para peneliti [19]. Adapun menurut [20] ekspektasi-ekspektasi dan variabelvariabel yang dimaksudkan adalah variabel kinerja, variabel usaha, variabel sosial dan faktor fasilitas.

Artikel ini bertujuan untuk mengungkapkan secara empiris regresi yang terjadi antara ekspektasi-ekspektasi dan faktorfaktor yang mempengaruhi terhadap sikap operator sebagai pengguna Sistem Informasi Pengelolaan Keuangan Daerah (SIPKD). Pendekatan deskriptif kuantitatif secara korelasional dilakukan dalam upaya untukdapat mengetahuiseberapa besar pengaruh antar variabel tersebut. Metode yang digunakan adalah teknik analisis regresi. Dengan demikian hasil yang diharapkan adalah dapat menjawab hipotesa $\left(\mathrm{H}_{1}\right)$ yakni apakah variabel kinerja berkontribusi positif yang signifikan terhadap sikap operator sistem informasi, $\left(\mathrm{H}_{2}\right)$ yakni apakah variabel usaha berkontribusi positif yang signifikan terhadap sikap operator sistem informasi, $\left(\mathrm{H}_{3}\right)$ yakni apakah variabel sosial berkontribusi positif yang signifikan terhadap sikap operator sistem informasi, $\left(\mathrm{H}_{4}\right)$ yakni apakah faktor kondisi fasilitas mempunyai pengaruh yang signifikan terhadap sikap operator sistem informasi.

\section{TINJAUAN PUSTAKA}

\subsection{Model-Model Adopsi Teknologi}

Interaksi antar manusia dengan sistem teknologi informasi tidak selalu berjalan mulus. Banyak penelitian yang telah mengungkapkan bahwa kemajuan dari suatu teknologi informasi tidak berhasil terimplementasi karena rendahnya tingkat serapan penerimaan pengguna. Persepsi pengguna pada suatu penerapan inovasi berdampak pada ujung teknologi, yakni apakah sistem itu sukses atau gagal dan seterusnya. Banyak peneliti seperti [21], menyatakan bahw ada delapan model yang dibuat dalam hal mengungkapkan variabel-variabel yang berkontribusi pada sikap seseorang terhadap penerapan atau adopsi dari suatu teknologi (Unified Theory of Acceptance and Use of Technology/UTAUT).

Model yang pertama, Theory of Reasoned Action (TRA) yang telah dikembangkan oleh Ajzen dan Fishbein. Model TRA yang merupakan suatu teori yang paling mendasar dan yang berkontribusi terhadap perilaku manusia. Teori ini dimulai dari mempelajari sikap atau perilaku seseorang terhadap penerapan atau adopsi dari suatu teknologi. Model TRA, menyatakan bahwa sikap atau perilaku seseorang diarahkan oleh niat atau keinginan untuk melakukannya, sehingga niat akan menentukan perilakunya [22].

Model yang kedua, Technology Acceptance Model (TAM) yang diperkenalkan oleh Fred D. Davis.TAM menganggap bahwa dua keyakinan individual, yaitu persepsi kegunaan dan persepsi kemudahan penggunaan adalah pengaruh utama untuk sikap yang mengarahkan perilaku terhadap suatu penerapan atau adopsi dari teknologi atau inovasi [23].

Model yang ketiga, Motivational Model (MM)menyatakan bahwa teori motivasi dapat menentukan sikap/perilaku. MM terdiri dari dua konstruk yaitu motivasi yang berasal dari dalam diri seseorang (intrinsic motivation) dan dari luar (extrinsic motivation). Persepsi seseorang mau menerapkanteknologi karena tidak ada alasan kuat yang jelas selain melakukannya.
Sedangkan dari luar diri dapat berupa peningkatan kinerja, penghasilan dan promosi jabatan[24].

Model yang keempat, Theory of Planned Behavior (TPB) merupakan perbaikan dari model TRA dengan adanya satu konstruk tambahan yaitu persepsi yang mengendalikan sikap (perceived behavioral control). Konstruk ini ditambahkan sebagai pengendali sikap individu[25].

Model yang kelima, kombinasi TAM dan TPB yang menambahkan variabel sikap berpengalaman dan yang tidak berpengalaman[26].

Model yang keenam, Model of PC Utilization (MPCU) yang menyatakan bahwa kebermanfaatan dari teknologi seperti komputer dapat mempengaruhi sikap seseorang dalam menggunakan atau tidak menggunakan teknologi tersebut [27].

Model yang ketujuh, Innovation Diffusion Theory (IDT) mendefinisikan difusi sebagai proses keuntungan relatif, kemudahan penggunaan, pencitraan, pandangan, konsisten terhadap nilai-nilai masa lalu, hasil nyata penggunaan inovasi, uji coba inovasi sebelum diadopsi dan sukarela dalam penggunaan inovasi [28].

Model yang kedelapan, Social Cognitive Theory (SCT) mempengaruhi sikap seseorang seperti perasaan, kecemasan dan penggunaan teknologi akibat dari hubungan timbal balik antara lingkungan, sikap dan kognitif [29].

\subsection{Teori Sikap}

Sikap merupakan komulatif dari niat yang terdapat di dalam diri individu yang paling tersembunyi terhadap legowo atau tidak legowonya seseorang pada sesuatu. Secara lebih nyata hal ini dapat diamati dari perilaku. Dimensi perilakulah yang dapat diukur dengan menetapkan prosedur yang menempatkan individual pada skala penilaian dua kondisi dan situasi misalnya baik atau buruk, halal atau haram dan lain sebagainya [30]. Adapun menurut [31] sikap adalah tindakan atau reaksi seseorang terhadap perubahan yang terjadi pada suatu lingkungan tertentu.

Sikap dapat didefinisikan pada tiga aspek yakni pengetahuan, keinginan dan tindakan [32]. Dari berbagai pandangan mengenai sikap tersebut dapat difahami bahwa sikap merupakan perilaku yang mengarahkan perasaan seseorang untuk memikirkan suatu objek yang baru yang membangkitkan rasa keinginan sebagai suatu reaksi untuk menerima, menolak dan sebagainya dengan tindakan atau pola tertentu.

\subsection{Ekspektasi Kinerja}

Ekspektasi kinerja (performance expectancy) diartikan sebagai seberapa tinggikah seseorang/individu mempercayai atau meyakini bahwa memfungsikan suatu inovasi teknologi akan dapat menolongnya untuk mendapatkan berbagai profit pada karir dan pekerjaan. Kinerja individu diharapkan selaras dengan kinerja organisasi [33].

Manfaat inovasi teknologi seperti teknologi informasi dan komunikasi yang pada abad 21, seperti sekarang ini sungguh tidak dapat dipisahkan, sangat berkaitan langsung dan tidak langsung bagi manusia dengan produktivitas usaha pada kerja dan karirnya yang efektif dan efisien. Pemanfaatan inovasi teknologi menunjukkan pilihan keputusan seseorang untuk memfungsikan atau tidak memfungsikannya sebagai variabel-variabel pokok yang dapat mempermudah melakukan suatu bidang pekerjaan. 
Ekspektasi kinerja berpengaruh terhadap niat penggunaan sistem informasi. Konstruksi variabel kinerja menjadi dominan atau yang paling kuat dalam niat penggunaan sistem informasi dalam situasi keterpaksaan maupun keberpasrahan [34]. Dapat dikatakan bahwa ekspektasi kinerja merupakan derjat seseorang mempercayai dan meyakini bahwa dengan melakukan dan menggunakan suatu perubahan dalam bekerja memanfaatkan teknologi informasi berbantuan komputer dapat membantu kinerjanya pada suatu bidang pekerjaan tertentu.

\subsection{Ekspektasi Usaha}

Ekspektasi usaha merupakan suatu taraf atau derajat dalam hal aspek menggunakan sesuatu. Sesuatu yang dimaksudkan adalah seseorang tidak membutuhkan pemikiran dan upaya yang besar untuk menggunakan inovasi teknologi. Kemudahan adalah indikasi bahwa user dengan senangnya beradaptasi dengan sistem yang baru oleh karena tidak banyak waktu yang dihabiskan untuk dapat akrab dengannya. Persepsi kemudahan penggunaan, diawali dari model TAM yang dapat dimaknai sebagai semudah apakah seseorang menggunakan suatu inovasi akan bebas dari aspek keberupayaannya [35]. Adapun menurut [36] mengatakan bahwa kesederhanaan penggunaan inovasi teknologi akan dapat menumbuhkan rasa percaya diri seseorang, bahwa sistem itu mempunyai kegunaan dan karenanya memunculkan rasa aman dan nyaman mengenakannya.

Beberapa indikator untuk menyatakan bahwa suatu inovasi dikatakan sederhana dalam hal mudah digunakan seperti mudah pengerjaannya, tidak dibutuhkan banyak tenaga dan sumber daya yang dilibatkannya untuk dioperasikan [37]. Bekerja dengan inovasi tersebut tidak sulit dan akan didapati keuntungan yang maksimal sebagai bentuk upaya dalam suatu bidang pekerjaan. Individu akan meyakini bahwa penggunaan inovasi itu akan memberikannya kelebihan manfaat dari yang sebelumnya ada.

Berdasarkan beberapa definisi tersebut diatas dapat difahami bahwa ekpektasi usaha merupakan aspek ketergunaan atau penggunaan inovasi. Praktis menjadi kata kunci yang dapat mewakili eksptektasi usaha oleh seseorang dalam menggunakan sesuatu hal yang baru.

\subsection{Faktor Sosial}

Faktor sosial merupakan variabel dominan dari niat penggunaan inovasi teknologi sebagaimana digambarkan oleh keterwakilan sejumlah variabel penting yang terbangun terkait dengan normatif yang berasal dari sekelompok perilaku yang terkonstruksi terhadap kesepakatan interpersonal yang dilakukan seseorang dengan orang lain pada lingkungan situasi sosial tertentu [38][39].

Faktor sosial diartikan bahwa seseorang/individu telah mempersepsikan dirinya dengan kepercayaan kepentingan yang diyakinnya akan mempengaruhi menggunakan sistem/inovasi. Faktor sosial merupakan pengaruh dari lingkungan sekitar individu bahwa dia harus menggunakan inovasi tersebut. Peran faktor sosial pada sikap penggunaan sistem informasi memiliki dampak pada perilaku individu.

Dapat disimpulkan bahwa faktor sosial merupakan faktorfaktor yang berasal dari lingkungan seseorang sehingga akan mempengaruhi seseorang dalam melakukan penggunaan teknologi atau sistem yang baru.

\subsection{Faktor Kondisi Fasilitas}

Variabel kondisi fasilitas diartikan sebagai seberapa jauh, suatu inovasi dipercaya sebagai sesuatu yang tetap dapat dihandalkan dengan nilai kompatibilitas dan kebutuhan dari pengguna potensial. Variabel kondisi fasilitas didefinisikan sebagai seberapa besar seseorang meyakini bahwa sarana dan prasarana yang mendukung sistem pada suatu infrastruktur organisasional dan teknikal tersedia dapat dihandalkan.

Konsep kondisi fasilitas seperti persepsi kontrol perilaku yang merupakan refleksi bahwa keyanikan memiliki batasanbatasan dari dalam dan luar seseorang pada perilaku yang meliputi persepsi sendiri (self-efficacy), keadaan kondisi fasilitas sumber daya dan keberadaan kondisi fasilitas. Faktor kondisi fasilitas dimaknai sebagai variabel-variabel objektif dilingkungan mana pengamatan menyetujui untuk membuat suatu tindakan dengan mudah dilakukan termasuk penyediaan dukungan komputer [40, 44].

Dapat disimpulkan bahwa variabel faktor kondisi fasilitas merupakan persepsi pengguna bahwa ketersediaan sumber daya dan fasilitas yang ada dan tersedia pada suatu institusi dan atau unitnya akan mendukung dalam pemanfaatan dan penggunaan teknologi sistem informasi berbantuan komputer.

\section{METODOLOGI}

Metodologi yang digunakan pada artikel ini adalah dengan pendekatan korelasi parsial dan regresi, dimana akan dilakukan suatu pembuktian terhadap dua variabel atau lebih untuk mengetahui dan mengungkapkan ada tidaknya hubungan yang mendukung antara satu variabel dengan variabel lainnya dengan pendekatan kuantitatif. Adapun variabel bebasnya $(\mathrm{X})$ adalah variabel kinerja $\left(\mathrm{X}_{1}\right)$, variabel usaha $\left(\mathrm{X}_{2}\right)$, variabel faktor sosial $\left(\mathrm{X}_{3}\right)$, dan variabel kondisi fasilitas $\left(\mathrm{X}_{4}\right)$. Sedangkan variabel terikatnya (Y) adalah sikap operator sistem informasi. Pada Gambar 1 akan dapat terlihat adanya suatu model hubungan antar variabel yang terbangun.

Tempat penelitian adalah diseluruh Satuan Kerja Perangkat Daerah (SKPD) yang terdiri dari Dinas, Badan, Kantor, Inspektorat, Sekretaris Dewan dan Kecamatan dan Kelurahan di Pemerintah Kota Solok yang menggunakan aplikasi SIPKD. Populasi yaitu berjumlah 134 orang dengan metode cluster random sampling diperoleh subjek ataupun objek yang menjadi responden penelitian sebanyak 44 responden.

Adapun kurun waktu riset yang dilaksanakan dimulai bulan November sampai Desember tahun 2015. Teknik pengumpulan data yang dipakai menggunakan instrumen angket atau lembarlembar kuesioner skala likert yang biasa diterapkan pada pengukuran persepsi sikap, pendapat dan lainnya dalam bidang keilmuan sosial seperti ilmu pendidikan dan psikologi. Teknik analisis data yang digunakan adalah dengan korelasi parsial dan regresi linear berganda dengan bantuan program paket aplikasi Statistical Package for the Social Sciences (SPSS) versi 22. 


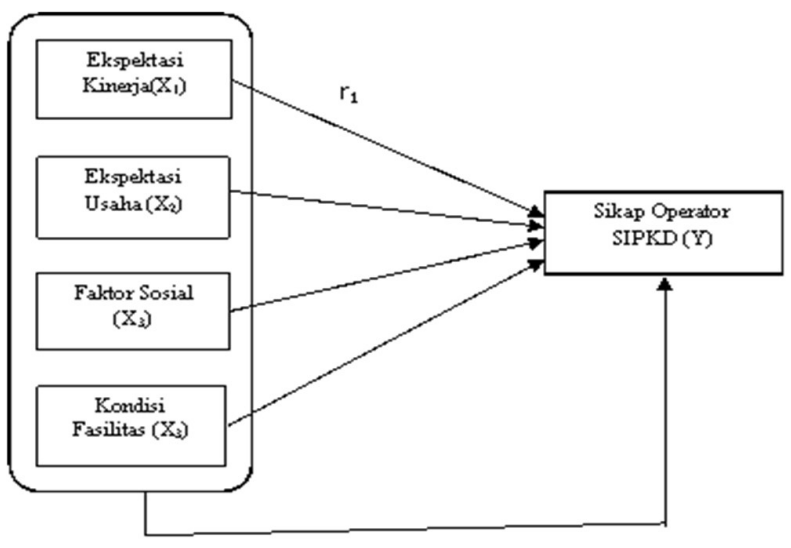

Gambar 1. Model hubungan antar variabel

Langkah-langkah yang dilakukan untuk menguji hipotesis dengan analisis regresi adalah dimulai dari analyze, pilih regression dan selanjutnya pilih linear. Masukkan variabel independen yang akan diuji ke dalam kotak independent dan variabel sikap operator sebagai variabel dependen ke dalam kotak dependent. Pilih metode enter dan selanjutnya ada tiga output yang dihasilkan yaitu angka yang diperoleh dari perhitungan variabel bebas terhadap variabel terikat, yakni koefisien regresi, hasil analisis regresi dan koefisien determinan.

\section{HASIL DAN PEMBAHASAN}

\subsection{Hasil}

Hipotesis yang telah dirumuskan, diuji dengan uji statistik yaitu dengan analisis regresi. Teknik analisis regresi sederhana digunakan untuk menguji hipotesis satu, dua, tiga dan empat yaitu menguji kontribusi setiap variabel-variabel bebas (ekspektasi kinerja, ekspektasi usaha, faktor sosial dan kondisi fasilitas) secara terpisah terhadap variabel terikat (sikap operator). Sedangkan hipotesis lima menggunakan regresi berganda yaitu menguji kontribusi variabel bebas secara bersama-sama terhadap variabel terikat.

Hipotesis yang pertama dilakukan untuk mengungkapkan kontribusi variabel ekspektasi kinerja terhadap variabel sikap operator SIPKD dengan menggunakan teknik regresi sederhana. Hasil pengolahan data dapat dilihat pada tabel berikut:

Tabel 1. Hasil uji koefisien regresi $\mathrm{X}_{1}$ terhadap $\mathrm{Y}$

\begin{tabular}{|c|c|c|c|c|c|c|}
\hline \multicolumn{7}{|c|}{ Coefficients ${ }^{a}$} \\
\hline & & $\begin{array}{r}\text { Unst } \\
\text { Co }\end{array}$ & $\begin{array}{l}\text { Tdardized } \\
\text { fficients }\end{array}$ & $\begin{array}{l}\text { Standardized } \\
\text { Coefficients }\end{array}$ & & \\
\hline \multicolumn{2}{|c|}{ Model } & B & Std. Error & Beta & $t$ & Sig. \\
\hline \multirow[t]{2}{*}{$\overline{1}$} & (Constant) & 27,739 & 6,055 & & 4,581 & .000 \\
\hline & $\begin{array}{l}\text { Ekspektasi } \\
\text { Kinerja }\end{array}$ & , 414 & 104 &, 52 & 3,976 &, 000 \\
\hline
\end{tabular}

Hasil nilai konstanta (a) sebesar 27,739 sedangkan ekspektasi kinerja $\left(\mathrm{X}_{1}\right)$ sebesar 0,414. Sehingga persamaan regresinya menjadi $\hat{\mathrm{Y}}=\mathrm{a}+\mathrm{bX}_{1}=27,739+0,414 \mathrm{X}_{1}$. Besar koefisien regresi variabel ekspektasi kinerja sebesar 0,414 menunjukkan bahwa ekspektasi kinerja berkontribusi secara positif dan signifikan terhadap sikap operator SIPKD. Setiap peningkatan ekspektasi kinerja sebesar satu satuan akan meningkatkan sikap operator sebesar 0,414 satuan atau dengan kata lain sikap operator akan naik jika ekspektasi kinerja ditingkatkan. Peningkatan ekspektasi kinerja $\left(\mathrm{X}_{1}\right)$ sebesar satu satuan, maka nilai sikap operator SIPKD akan bertambah sebesar 28,153 . Pengujian variabel ekspektasi kinerja $\left(\mathrm{X}_{1}\right)$ terhadap sikap operator SIPKD:

$\mathrm{H}_{0}: \mathrm{b}_{1}=0 \quad$ Ekspektasi Kinerja tidak berkontribusi terhadap Sikap Operator SIPKD

$\mathrm{H}_{1}: \mathrm{b}_{1} \neq 0$ Ekspektasi Kinerja berkontribusi terhadap Sikap Operator SIPKD

Berdasarkan hal tersebut dapat diketahui nilai thitung sebesar 3,976 sedangkan tabel pada taraf signifikansi $5 \%(\alpha=0,05)$ adalah 2,018 , artinya $t_{\text {hitung }}>\mathrm{t}_{\text {tabel }}(3,976>2,018)$ dengan nilai signifikan sebesar $0,000<0,05$. Ini berarti harga $\mathrm{t}$ hitung signifikan, sehingga disimpulkan terdapat korelasi positif dan signifikan antara ekspektasi kinerja dan sikap operator. Maka $\mathrm{H}_{0}$ ditolak dan $\mathrm{H}_{1}$ diterima, yang berarti ekspektasi kinerja $\left(\mathrm{X}_{1}\right)$ berkontribusi terhadap sikap operator $\operatorname{SIPKD}(\mathrm{Y})$.

Tabel 2. Koefisien Determinasi $\mathrm{X}_{1}$ terhadap $\mathrm{Y}$

\begin{tabular}{l|r|r|r|r}
\hline \multicolumn{5}{c|}{ Model Summary $^{b}$} \\
\hline Model & $r$ & R Square & \multicolumn{1}{c}{$\begin{array}{c}\text { Adjusted R } \\
\text { Square }\end{array}$} & $\begin{array}{c}\text { Std. Error of the } \\
\text { Estimate }\end{array}$ \\
\hline 1 &, $523^{\mathrm{a}}$ &, 274 &, 256 & 5,50600 \\
\hline
\end{tabular}

a. Predictors: (Constant), Ekspektasi_Kinerja

b. Dependent Variable: Sikap_Operator

Nilai korelasi (r) antara variabel ekspektasi kinerja $\left(\mathrm{X}_{1}\right)$ dengan sikap operator $(\mathrm{Y})$ sebesar 0,523 . Nilai koefisien determinasi $R$ Square (R2) sebesar 0,274 yang berarti bobot keeratan hubungan antara variabel ekspektasi kinerja dan sikap operator adalah sebesar 0,274 atau sebesar $27,4 \%$.

Hipotesis kedua dilakukan untuk mengetahui kontribusi variabel ekspektasi usaha terhadap variabel sikap operator SIPKD. Hasil pengolahan data dapat dilihat pada tabel berikut:

Tabel 3. Hasil uji koefisien regresi $\mathrm{X}_{2}$ terhadap $\mathrm{Y}$

\begin{tabular}{|c|c|c|c|c|c|c|}
\hline \multicolumn{7}{|c|}{ Coefficients $^{a}$} \\
\hline & & \multicolumn{2}{|c|}{$\begin{array}{c}\text { Unstandardized } \\
\text { Coefficients }\end{array}$} & $\begin{array}{l}\text { Stand ardized } \\
\text { Coefficients }\end{array}$ & & \\
\hline \multicolumn{2}{|c|}{ Model } & B & Std. Error & Beta & $t$ & Sig. \\
\hline \multirow[t]{2}{*}{1} & (Constant) & 22,036 & 6,535 & & 3,372 & ,002 \\
\hline & Ekspektasi Usaha &, 783 & 172 & .575 & 4,557 & .000 \\
\hline
\end{tabular}

Hasil nilai konstanta (a) yaitu sebesar 22,036 sedangkan ekspektasi usaha $\left(\mathrm{X}_{2}\right)$ sebesar 0,783. Sehingga persamaan regresinya menjadi $\hat{\mathrm{Y}}=\mathrm{a}+\mathrm{bX}_{2}=22,036+0,783 \mathrm{X}_{2}$. Besar koefisien regresi variabel ekspektasi usaha sebesar 0,783 menunjukkan bahwa ekspektasi usaha berkontribusi secara positif dan signifikan terhadap sikap operator SIPKD.

Setiap peningkatan ekspektasi usaha sebesar satu satuan akan meningkatkan sikap operator sebesar 0,783 satuan atau peningkatan ekspektasi usaha sebesar satu satuan, maka nilai sikap operator SIPKD akan bertambah sebesar 22,819. Sikap operator akan naik jika ekspektasi usaha ditingkatkan.Pengujian variabel ekspektasi usaha $\left(\mathrm{X}_{2}\right)$ terhadap sikap operator SIPKD:

$\mathrm{H}_{0}: \mathrm{b}_{2}=0$ Ekspektasi usaha tidak berkontribusi terhadap sikap Operator SIPKD

$\mathrm{H}_{2}: \mathrm{b}_{2} \neq 0 \quad$ Ekspektasi usaha berkontribusi terhadap sikap operator SIPKD

Dapat diketahui bahwa nilai thitung sebesar 4,557 sedangkan tabel pada taraf signifikansi $5 \%(\alpha=0,05)$ adalah 2,018 , artinya $t_{\text {hitung }}>t_{\text {tabel }}(4,557>2,018)$ dengan nilai signifikan sebesar 
$0,000<0,05$ yang berarti harga $t$ hitung signifikan, sehingga disimpulkan terdapat korelasi positif dan signifikan antara ekspektasi kinerja dan sikap operator. Maka $\mathrm{H}_{0}$ ditolak dan $\mathrm{H}_{2}$ diterima, yang berarti ekspektasi usaha $\left(\mathrm{X}_{2}\right)$ berkontribusi terhadap sikap operator SIPKD (Y).

Tabel 4. Koefisien Determinasi $\mathrm{X}_{2}$ terhadap Y

\begin{tabular}{|c|c|c|c|c|}
\hline \multicolumn{5}{|c|}{ Model Summary } \\
\hline Model & $r$ & R Square & $\begin{array}{l}\text { Adjusted R } \\
\text { Square }\end{array}$ & $\begin{array}{l}\text { Std. Error of the } \\
\text { Estimate }\end{array}$ \\
\hline 1 &, $575^{a}$ & 331 & 315 & 5,28442 \\
\hline
\end{tabular}

Berdasarkan nilai korelasi (r) antara variabel ekspektasi usaha $\left(\mathrm{X}_{2}\right)$ dengan sikap operator $(\mathrm{Y})$ yaitu sebesar 0,575 . Nilai koefisien determinasi R Square (R2) variabel ekspektasi usaha dan sikap operator adalah sebesar 0,331 . Artinya bobot keeratan hubungan antara variabel ekspektasi usaha dengan variabel sikap operator adalah 0,331 atau sebesar $33,1 \%$.

Hipotesis ketiga dilakukan untuk mengetahui kontribusi variabel faktor sosial terhadap variabel sikap operator SIPKD. Hasil pengolahan data dapat dilihat pada tabel berikut:

Tabel 5. Hasil uji koefisien regresi $\mathrm{X}_{3}$ terhadap $\mathrm{Y}$

\begin{tabular}{|c|c|c|c|c|c|c|}
\hline \multicolumn{7}{|c|}{ Coefficients $^{a}$} \\
\hline & & \multicolumn{2}{|c|}{$\begin{array}{c}\text { Unstandardized } \\
\text { Coefficients }\end{array}$} & \multirow{2}{*}{$\begin{array}{c}\begin{array}{c}\text { Standardized } \\
\text { Coefficients }\end{array} \\
\text { Beta }\end{array}$} & \multirow[b]{2}{*}{$\mathrm{t}$} & \multirow[b]{2}{*}{ Sig. } \\
\hline \multicolumn{2}{|c|}{ Model } & B & Std. Error & & & \\
\hline \multirow[t]{2}{*}{1} & (Constant) & 25,672 & 6,491 & & 3,955 &, 000 \\
\hline & Faktor_Sosial &, 550 & , 137 & ,528 & 4,026 &, 000 \\
\hline
\end{tabular}

Koefisien regresi variabel faktor sosial dan sikap operator menunjukkan hasil nilai konstanta (a) yaitu sebesar 25,672 sedangkan faktor sosial $\left(\mathrm{X}_{3}\right)$ sebesar 0,550 . Sehingga persamaan regresinya adalah $\hat{\mathrm{Y}}=\mathrm{a}+\mathrm{bX}_{3}=25,672+0,550 \mathrm{X}_{3}$. Koefisien regresi variabel faktor sosial sebesar 0,550 menunjukkan bahwa faktor sosial berkontribusi secara positif dan signifikan terhadap sikap operator SIPKD.

Setiap peningkatan faktor sosial akan meningkatkan sikap operator. Peningkatan faktor sosial sebesar satu satuan, maka nilai sikap operator SIPKD akan bertambah sebesar 26,222.Pengujian variabel faktor sosial $\left(\mathrm{X}_{3}\right)$ terhadap sikap operator SIPKD:

$\mathrm{H}_{0}: \mathrm{b}_{3}=0$ Faktor sosial tidak berkontribusi terhadap sikap Operator SIPKD

$\mathrm{H}_{3}: \mathrm{b}_{3} \neq 0$ Faktor sosial berkontribusi terhadap sikap operator SIPKD.

Dapat diketahui bahwa nilai thitung sebesar 4,026 sedangkan $t_{\text {tabel }}$ pada taraf signifikansi $5 \%(\alpha=0,05)$ adalah 2,018 , artinya thitung besar dari ttabel $(4,026>2,018)$ dengan nilai signifikan sebesar $0,000<0,05$ maka $\mathrm{H}_{0}$ ditolak dan $\mathrm{H}_{3}$ diterima, yang berarti faktor sosial $\left(\mathrm{X}_{3}\right)$ berkontribusi terhadap sikap operator $\operatorname{SIPKD}(\mathrm{Y})$.

Tabel 6. Koefisien Determinasi $\mathrm{X}_{3}$ terhadap $\mathrm{Y}$

\begin{tabular}{|c|c|c|c|c|}
\hline \multicolumn{5}{|c|}{ Model Summaryb } \\
\hline Model & $\mathrm{r}$ & R Square & $\begin{array}{c}\text { Ad justed } R \\
\text { Square }\end{array}$ & $\begin{array}{c}\text { Std. Error of the } \\
\text { Estimate }\end{array}$ \\
\hline 1 & $.528^{a}$ & 278 & .261 & 5,48732 \\
\hline
\end{tabular}

Krismadinata
Berdasarkan hasil nilai korelasi (r) antara variabel faktor sosial $\left(\mathrm{X}_{3}\right)$ dengan sikap operator $(\mathrm{Y})$ sebesar 0,528 . Nilai koefisien determinasi R Square (R2) sebesar 0,278 yang berarti bobot keeratan hubungan antara variabel faktor sosial dengan sikap operator adalah 0,278 atau sebesar $27,8 \%$.

Hipotesis keempat dilakukan untuk mengetahui kontribusi variabel kondisi fasilitas terhadap variabel sikap operator SIPKD. Hasil pengolahan data dapat dilihat pada tabel berikut:

Tabel 7. Hasil uji koefisien regresi $\mathrm{X}_{4}$ terhadap $\mathrm{Y}$

\begin{tabular}{|c|c|c|c|c|c|c|}
\hline \multicolumn{7}{|c|}{ Coefficients $^{\mathrm{a}}$} \\
\hline & & \multicolumn{2}{|c|}{$\begin{array}{l}\text { Unstandardized } \\
\text { Coefficients }\end{array}$} & \multirow{2}{*}{$\begin{array}{c}\text { Standardized } \\
\text { Coefficients } \\
\text { Beta } \\
\end{array}$} & \multirow[b]{2}{*}{$\mathrm{t}$} & \multirow[b]{2}{*}{ Sig. } \\
\hline \multicolumn{2}{|c|}{ Model } & B & Std. Error & & & \\
\hline \multirow[t]{2}{*}{1} & (Constant) & 33,601 & 8,364 & & 4,017 &, 000 \\
\hline & Kondisi Fasilitas & ,410 & ,189 & ,317 & 2,164 &, 036 \\
\hline
\end{tabular}

Nilai konstanta (a) sebesar 33,601 sedangkan kondisi fasilitas $\left(\mathrm{X}_{4}\right)$ sebesar 0,410 . Sehingga persamaan regresinya adalah $\hat{\mathrm{Y}}=\mathrm{a}+\mathrm{bX}_{4}=33,601+0,410 \mathrm{X}_{4}$. Besar koefisien regresi variabel kondisi fasilitas sebesar 0,410 menunjukkan bahwa kondisi fasilitas berkontribusi secara positif dan signifikan terhadap sikap operator SIPKD.

Setiap peningkatan kondisi fasilitas akan menaikkan sikap operator. Peningkatan kondisi fasilitas sebesar satu satuan akan meningkatkan sikap operator sebesar 0,410 satuan atau dengan kata lain, atau peningkatan kondisi fasilitas sebesar satu satuan, maka nilai sikap operator SIPKD akan bertambah sebesar 34,011.Pengujian variabel kondisi fasilitas $\left(\mathrm{X}_{4}\right)$ terhadap sikap operator SIPKD:

$\mathrm{H}_{0}: \mathrm{b}_{4}=0$ Kondisi fasilitas tidak berkontribusi terhadap sikap Operator SIPKD

$\mathrm{H}_{4}: \mathrm{b}_{4} \neq 0 \quad$ Kondisi fasilitas berkontribusi terhadap sikap operator SIPKD.

Dapat diketahui bahwa nilai thitung sebesar 2,164 sedangkan tabel pada taraf signifikansi $5 \%(\alpha=0,05)$ adalah 2,018 artinya thitung lebih besar dari ttabel $(2,164>2,018)$ dengan nilai signifikan sebesar $0,036<0,05$ maka $\mathrm{H}_{0}$ ditolak dan $\mathrm{H}_{4}$ diterima, yang berarti kondisi fasilitas $\left(\mathrm{X}_{4}\right)$ berkontribusi terhadap sikap operator SIPKD (Y).

Tabel 8. Koefisien Determinasi $\mathrm{X}_{4}$ terhadap Y

\begin{tabular}{|l|r|r|r|c}
\hline \multicolumn{5}{|c}{ Model Sum mary } \\
\hline Model & $\mathrm{R}$ & R Square & $\begin{array}{c}\text { Ad justed R } \\
\text { Square }\end{array}$ & $\begin{array}{c}\text { Std. Error of the } \\
\text { Estimate }\end{array}$ \\
\hline 1 &, $317^{\mathrm{a}}$ &, 100 &, 079 & 6,12722 \\
\hline
\end{tabular}

a. Pre dictors: (Con sta $\mathrm{nt}$ ), Kondisi_Fasilitas

b. Dependent Variable: Sikap_Operator

Berdasarkan hasil nilai korelasi (r) antara variabel kondisi fasilitas $\left(\mathrm{X}_{4}\right)$ dengan sikap operator $(\mathrm{Y})$ sebesar 0,317. Nilai koefisien determinan yang diketahui dari angka R Square (R2) yang ditunjukkan sebesar 0,100 yang berarti bobot keeratan hubungan antara variabel kondisi fasilitas $\left(\mathrm{X}_{4}\right)$ dengan sikap operator (Y) adalah sebesar $10 \%$.

Pengujian hipotesis kelima dilakukan untuk mengetahui ada tidaknya kontribusi variabel ekspektasi kinerja $\left(\mathrm{X}_{1}\right)$, ekspektasi usaha $\left(\mathrm{X}_{2}\right)$, faktor sosial $\left(\mathrm{X}_{3}\right)$, dan kondisi fasilitas $\left(\mathrm{X}_{4}\right)$ secara bersama-sama terhadap variabel sikap operator SIPKD (Y). Persamaan regresi berganda digunakan untuk mencari 
kontribusiterhadap sikap operator SIPKD dilakukan dengan uji $\mathrm{F}$ (analisis regresi variabel independen terhadap variabel dependen). Pengujian variabel $\mathrm{X}_{1}, \mathrm{X}_{2}, \mathrm{X}_{3}$ dan $\mathrm{X}_{4}$ terhadap $\mathrm{Y}$ adalah:

$\mathrm{H}_{0}: \mathrm{b}_{5}=0$ ekspektasi kinerja, ekspektasi usaha, faktor sosialdan kondisi fasilitas tidak berkontribusi terhadap sikap operator SIPKD

$\mathrm{H}_{5}: \mathrm{b}_{5} \neq 0$ ekspektasi kinerja, ekspektasi usaha, faktor sosialdan kondisi fasilitas berkontribusi terhadap sikap operator SIPKD

Tabel 9. Hasil uji analisis $\mathrm{X}_{1}, \mathrm{X}_{2}, \mathrm{X}_{3}$, dan $\mathrm{X}_{4}$ terhadap $\mathrm{Y}$

\begin{tabular}{|c|c|c|c|c|c|c|}
\hline \multicolumn{7}{|c|}{ ANOVA $^{a}$} \\
\hline \multicolumn{2}{|c|}{ Model } & Sum of Squares & $\mathrm{df}$ & Mean Square & $\mathrm{F}$ & Sig. \\
\hline \multirow[t]{3}{*}{1} & Regression & 884,059 & 4 & 221,015 & 9,924 &, $000^{b}$ \\
\hline & Residual & 868,577 & 39 & 22,271 & & \\
\hline & Total & 1752,636 & 43 & & & \\
\hline
\end{tabular}

Berdasarkan nilai $\mathrm{F}$ hitung sebesar 9,924 pada taraf signifikan 0,000. Nilai $F$ tabel pada taraf signifikansi $5 \%(\alpha=0,05)$ adalah sebesar 2,61. Kriteria uji $F$ adalah jika $F_{\text {hitung }}>F_{\text {tabel }}$ maka hipotesis nol ditolak dan hipotesis alternatif diterima. Dan jika Fhitung $<\mathrm{F}_{\text {tabel }}$ maka hipotesis 0 diterima dan hipotesis dari alternatif ditolak. Berdasarkan hasil perhitungan, nilai $\mathrm{F}$ hitung lebih besar dari nilai $\mathrm{F}$ tabel $(9,924>2,61)$, dengan nilaisignifikansi adalah $0,000<0,05$. Sehingga keputusan yang diambil adalah H5 diterima.

Seluruh variabel independen yaitu ekspektasi kinerja, ekspektasi usaha, faktor sosial, dan kondisi fasilitas secara bersama-sama berkontribusi terhadap sikap operator SIPKD.Untuk mendapatkan nilai regresi variabel bebas secara bersama-sama terhadap variabel terikat dapat dilihat pada tabel berikut:

Tabel 10. Hasil uji koefisien regresi $\mathrm{X}_{1}, \mathrm{X}_{2}, \mathrm{X}_{3}$, dan $\mathrm{X}_{4}$ terhadap $\mathrm{Y}$

\begin{tabular}{|c|c|c|c|c|c|c|}
\hline \multicolumn{7}{|c|}{ Coefficients $^{\mathrm{a}}$} \\
\hline & & \multicolumn{2}{|c|}{$\begin{array}{c}\text { Unstandardized } \\
\text { Coefficients }\end{array}$} & \multirow{2}{*}{$\begin{array}{c}\begin{array}{c}\text { Standardized } \\
\text { Coefficients }\end{array} \\
\text { Beta } \\
\end{array}$} & \multirow[b]{2}{*}{$\mathrm{t}$} & \multirow[b]{2}{*}{ Sig. } \\
\hline \multicolumn{2}{|c|}{ Model } & $\mathrm{B}$ & Std. Error & & & \\
\hline \multirow[t]{5}{*}{1} & (Constant) & 5,730 & 8,132 & &, 705 &, 485 \\
\hline & Ekspektasi_Kinerja & 233 & 100 & 294 & 2,326 &, 025 \\
\hline & Ekspektasi_Usaha &, 484 &, 179 &, 355 & 2,703 &, 010 \\
\hline & Faktor_Sosial & 275 & 135 & 264 & 2,041 &, 048 \\
\hline & Kondisi_Fasilitas & 027 & 161 & 021 & ,169 & ,866 \\
\hline
\end{tabular}

Nilai konstanta sebesar 5,730, ekspektasi kinerja $\left(\mathrm{X}_{1}\right)$ sebesar 0,233 , ekspektasi usaha $\left(\mathrm{X}_{2}\right)$ sebesar 0,484 , faktor sosial $\left(X_{3}\right)$ 0,275 dan kondisi fasilitas $\left(X_{4}\right)$ sebesar 0,027. Sehinggga persamaan regresinya adalah $\hat{\mathrm{Y}}=\mathrm{a}+\mathrm{b}_{1} \mathrm{X}_{1}+\mathrm{b}_{2} \mathrm{X}_{2}+\mathrm{b}_{3} \mathrm{X}_{4}+\mathrm{b}_{4} \mathrm{X}_{4}$ dan $\hat{Y}=5,730+0,233 X_{1}+0,484 X_{2}+0,275 X_{3}+0,027 X_{4}$.

Pengolahan data menunjukkan nilai signifikansi untuk variabel ekspektasi kinerja, ekspektasi usaha dan faktor sosial $<0,05$, sedangkan untuk variabel kondisi fasilitas $>0,05$.

Daya ramal variabel ekspektasi kinerja, ekspektasi usaha, faktor sosial terhadap sikap operator SIPKD adalah signifikan/bermakna, sedangkan daya ramal kondisi fasilitas terhadap sikap operator, tidak bermakna/tidak signifikan.

Tabel 11. Koefisien Determinasi $\mathrm{X}_{1}, \mathrm{X}_{2}, \mathrm{X}_{3}$, dan $\mathrm{X}_{4}$ terhadap $\mathrm{Y}$

\begin{tabular}{|c|c|c|c|c|}
\hline \multicolumn{5}{|c|}{ Model Sum maryb } \\
\hline Model & $\mathrm{R}$ & R Square & $\begin{array}{c}\text { Adjusted R } \\
\text { Square }\end{array}$ & $\begin{array}{c}\text { Std. Error of the } \\
\text { Estimate }\end{array}$ \\
\hline 1 &, $710^{\mathrm{a}}$ &, 504 &, 454 & 4,71924 \\
\hline
\end{tabular}

Berdasarkan hasil pada analisis data Tabel 11 diatas, dapat diketahui bahwa nilai korelasi variabel bebas yaitu ekspektasi kinerja, ekspektasi usaha, faktor sosial dan kondisi fasilitas secara bersama-sama terhadap variabel sikap operator sebesar 0,710 sedangkan nilai koefisien determinasi $\left(\mathrm{R}^{2}\right)$ adalah 0,504 . Hal ini menunjukkan bahwa bobot keeratan hubungan variabel ekspektasi kinerja, ekspektasi usaha, faktor sosial dan kondisi fasilitas terhadap sikap operator adalah 0,504 atau sebesar 50,4\%.

Nilai $\mathrm{R}^{2}$ menjadi dasar perhitungan sumbangan relatif dan sumbangan efektif variabel-variabel yang ada. Angka-angka yang ditunjukkan dari hasil analisis, menjadi sumbangan relatif (SR) dan sumbangan efektif (SE) dari sejumlah variabel, yakni variabel kinerja, usaha, sosial dan kondisi fasilitas terhadap sikap operator diperoleh dari perhitungan dengan rumus crossproduct dan analisis data regression.

\subsection{Pembahasan}

Dapat diketahui bahwa analisis regresi menunjukkan bahwa ada hubungan yang positif antara ekspektasi kinerja dengan sikap operator SIPKD. Berdasarkan hal tersebut dikatakan bahwa semakin baik ekspektasi kinerja maka akan semakin baik sikap operator SIPKD. Sebaliknya semakin rendah ekspektasi kinerja maka semakin rendah pula sikap operator dalam menggunakan SIPKD. Sumbangan relatif variabel ekspekasi kinerja terhadap sikap operator adalah sebesar 30,55\% dan dan sumbangan efektif ekspektasi kinerja sebesar 15,4\%.

Dari analisis regresi mengungkapkan bahwa ada korelasi yang positif antara ekspektasi usaha dengan sikap operator SIPKD.Berdasarkan hal tersebut dikatakan bahwa semakin baik ekspektasi usaha maka akan semakin baik sikap operator SIPKD. Sebaliknya semakin rendah ekspektasi usaha maka semakin rendah pula sikap operator dalam menggunakan SIPKD. Sumbangan relatif variabel ekspektasi usaha sebesar $40,52 \%$ dan sumbangan efektif sebesar 20,4\%.

Analisis regresi menunjukkan bahwa ada hubungan yang positif antara faktor sosial dengan sikap operator SIPKD.Berdasarkan hal tersebut dikatakan bahwa semakin baik faktor sosial maka akan semakin baik sikap operator SIPKD. Sebaliknya semakin rendah faktor sosial maka semakin rendah pula sikap operator dalam menggunakan SIPKD.Hal ini mengisyaratkan bahwa faktor sosial seperti rekan kerja, atasan, lingkungan kerja, instansi dan pemerintah daerah memiliki andil besar dalam mensukseskan implementasi SIPKD.Sumbangan relatif faktor sosial terhadap sikap operator adalah 27,6\% sedangkan sumbangan efektif faktor sosial terhadap sikap operator adalah $13,9 \%$.

Hasil lain menunjukan bahwa ada hubungan yang positif antara kondisi fasilitas dengan sikap operator SIPKD.Ketersediaan sumber daya seperti infrastruktur, saranadan waktu respon sistem akan membuat operator memiliki sikap yang lebih baik dalam menggunakan aplikasi SIPKD.

Jika dibandingkan dengan variabel lain, kontribusi kondisi fasilitas cukup kecil, hal ini disebabkan oleh karena responden merasa bahwa kondisi fasilitas saat ini belum cukup memadai, 
tidak memiliki ruang khusus untuk entri data dan akses ke pusat pengolahan data lambat serta sering terjadi error sistem. Sumbangan relatif yang didapatkan adalah $1,32 \%$ sedangkan sumbangan efektif adalah $0,7 \%$.

Secara parsial bahwa variabel ekspektasi kinerja, ekspektasi usaha dan faktor sosial, berkontribusi signifikan. Dengan kata lain, daya ramalnya signifikan. Hal ini menjelaskan bahwa ketiga variabel tersebut mampu sebagai prediktor yang baik terhadap sikap operator SIPKDdengan syarat variabel kondisi fasilitas dalam keadaan tetap atau konstan. Sehingga dikatakan bahwa kontribusi variabel kondisi fasilitas positif tetapi tidak signifikan atau tidak bermakna atau daya ramal variabel kondisi fasilitas terhadap sikap operator tidak begitu signifikan. Artinya variabel kondisi fasilitas tidak berkontribusi secara signifikan jika variabel lain dalam keadaan tetap/konstan.

Hasil yang diperoleh menunjukkan variabel kondisi fasilitas dapat menjadi prediktor bagi sikap operator namun tidak signifikan.Kemudian hal tersebut menunjukkan bahwa data yang diperoleh dari respondentelah dilakukan uji normalitasnya dengan tujuan untuk memenuhi kriteria model regresi yang baik.

Hasil uji normalitas data diperlihatkan oleh diagram histogram seperti pada Gambar 2.

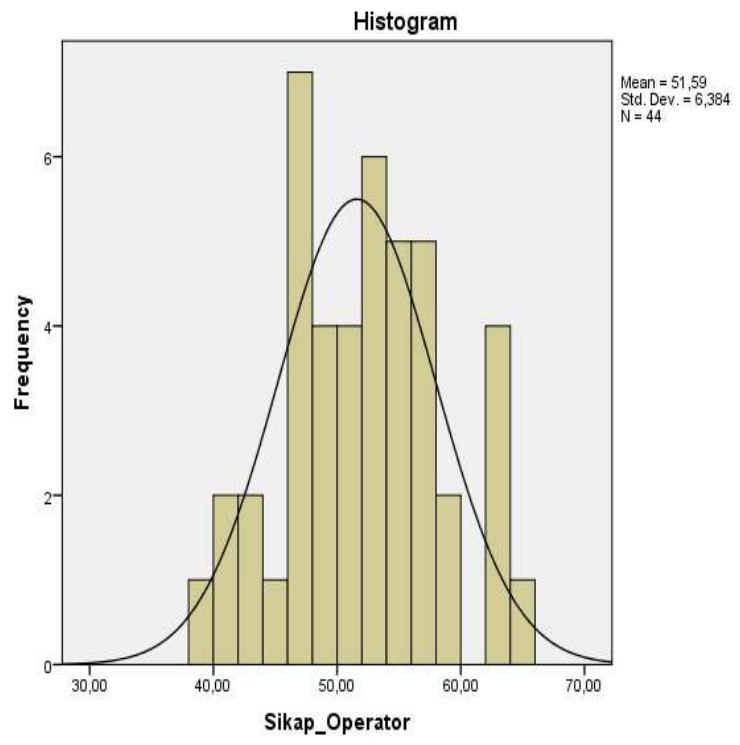

Gambar 2. Hasil uji normalitas data

Dari penjelasan diatas dapat dikatakan bahwa model penelitian yang dihasilkan mampu menjelaskan sikap operator dalam menggunakan aplikasi SIPKD, seperti yang yang terlihat pada Gambar 3.

Ekspektasi usaha dari operator, memberikan kontribusi terbesar terhadap sikap operator SIPKD, sedangkan kondisi fasilitas memberikan kontribusi paling kecil terhadap sikap operator.

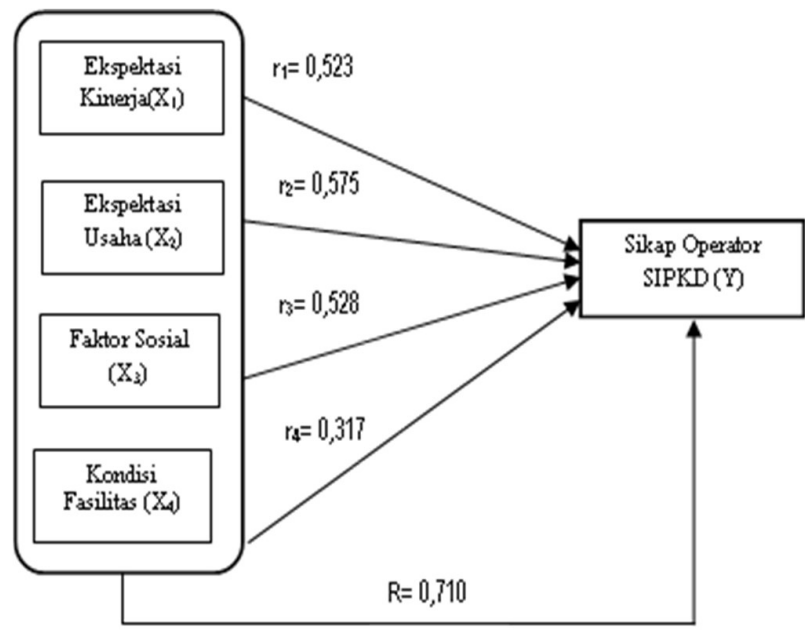

Gambar 3. Hasil akhir model hubungan antar variabel

\section{KESIMPULAN DAN SARAN}

Seberapa besar kontribusi dari masing-masing variabel yakni ekspektasi kinerja, usaha, faktor sosial dan fasilitas terhadap sikap operator sistem informasi telah berhasil diungkapkan dan dijelaskan serta seberapa besar kontribusi masing-masing variabel bebas terhadap variabel terikat telahpun dapat diketahui.

Variabel ekspektasi kinerja, ekspektasi usaha, faktor sosial dan kondisi fasilitas berkontribusi positif atau berpersepsi positif terhadap sikap operator SIPKD. Dari keempat variabel bebas tersebut, ekspektasi usaha memiliki sumbangan relatif dan sumbangan efektif tertinggi. Secara totalitas, sikap operator dalam menggunakan aplikasi SIPKD dikatakan cukup baik.

Model penelitian ini diharapkan dapat dikembangkan lebih dalam lagi dengan memperhatikan faktor manusia secara utuh misalnya aspek motif karena manusia adalah pemeran utama atau sebagai entitas pokok dari suatu penerapan dan penggunaan sistem informasi berbantuan komputer.

\section{DAFTAR PUSTAKA}

[1] Kurniabudi and Assegaff, S. "Analisis Perilaku Penerimaan Edmodo padaPerkuliahan dengan Model UTAUT", TEKNOSI, volume 02(03), 2016, pages,1-10, https://doi.org/10.25077/TEKNOSI.v2i3.2016.1-10.

[2] Assegaff, S, et al, "User Behavior in Adopt Mobile Commerce (Scale Development: Perspective of Trust and Risk )", Jurnal Teknologi dan Sistem Informasi, volume 03(03),2017, pages 320-325, https://doi.org/10.25077/TEKNOSI.v3i3.2017.320-325.

[3] Bendi, R. K. J and Andayani, S, "Analisis Perilaku Penggunaan Sistem Informasi Menggunakan Model UTAUT", Seminar Nasional Teknologi Informasi \& Komunikasi Terapan (SEMANTIK),2013, pages 277282.

[4] Bendi, R. K. J, et al, "Analisis Pengaruh Perbedaan Gender pada Model UTAUT", Seminar Nasional Teknologi Informasi \& Komunikasi Terapan (SEMANTIK), 2014, pages 228-234.

[5] Wilson, J. R and Sharples, S. Evaluation of Human Work (Fourth Edition). CRC Press, Florida. 2015. pp.iii-984. 
[6] Ince, D. C, et al, "The Case for Open Computer Programs", Nature, volume 482, 2012, pages 485488,https://doi:10.1038/nature10836.

[7] Shute, J, et al, "F1: A Distributed SQL Database That Scales", in Conference Proceedings on Very Large Data Bases, 2013, pages 1068-1079.

[8] Dewi, S and Utami, D, "Penilaian Efektivitas Penerapan Sistem Informasi Akuntansi Berbasis Komputer pada SKPD PEMKAB Tabanan", in Seminar Nasional UNUD, Bali, Indonesia", pages 1-20.

[9] Putu, $\mathrm{N}$ et al, "Penggunaan Teknologi Informasi Akuntansi Terhadap Kinerja Individual Pada PT. Bank Pembangunan Daerah", e-Journal S1 Ak Universitas Pendidikan Ganesha," volume 1, 2015. pages 1-10.

[10] Wang, C, "The Evolution of Social Commerce: The People, Management, Technology, and Information Dimensions and Information Dimensions", Communications of the Association for Information Systems, volume 31, 2012. pages 105-127. http://aisel.aisnet.org/cais/vol31/iss1/5C.

[11] Williams, M, D, et al, "The Unified Theory of Acceptance and Use of Technology (UTAUT): ALiterature Review", Journal of Enterprise Information Management, Volume 28(3), 2015. pages 443-488, https://doi.org/10.1108/JEIM-09-2014-0088.

[12] Taiwo, A. Aand Downe,A. G, "The Theory Of User Acceptance And Use Of Technology (UTAUT): A Meta-Analytic Review Of Empirical Findings", Journal of Theoretical and Applied Information Technology, volume 49, 2013, pages 48-58, www.jatit.org.

[13] Alshehri, M and Drew, S, "The Effects of Website Quality on Adoption of E-Government Service: An Empirical Study Applying UTAUT Model Using SEM", in Conference Proceedings $23^{\text {rd }}$ Australasian On Information Systems,3-5 Dec 2012, Geelong, pages 113.

[14] T. Escobar-rodríguez and E. Carvajal-trujillo, "Online Purchasing Tickets for Low Cost Carriers: An Application of the Unified Theory of Acceptance and Use of Technology (UTAUT) Model" Tour. Manag, volume 43,2014, pages 70-88, http://dx.doi.org/10.1016/j.tourman.2014.01.017.

[15] Jeng, D. J and Tzeng, G"Computers \& Industrial Engineering Social Influence on the Use of Clinical Decision Support Systems: Revisiting the Unified Theory of Acceptance and Use of Technology by the Fuzzy DEMATEL Technique," Comput. Ind. Eng, volume 62, 2012, pages 819-828.

[16] Sukreni, K et al, "Korelasi Antara Perilaku Penggunaan Media Sosial Kreativitas Belajar Dan Prestasi Belajar TIK Siswa Di SMA Negeri 1 Sawan Pada Semester Ganjil Tahun Ajaran", KARMAPATI, volume 4(4), 2015,pages 1-8.

[17] Yu, Chian-Son, "Factors Affecting Individuals To Adopt Mobile Banking: Empirical Evidence From The UTAUT Model", Journal of Electronic Commerce Research, volume13,2012, pages 104-121.

[18] Hamari, J, "Social Motivations To Use Gamification: An Empirical Study Of Gamifying Exercise", in Conference Proceedings ECIS 2013 Completed Research. 105, pages 1-12.

[19] Syaukani, M, et al, "Analisis Faktor-Faktor yang Mempengaruhi Minat Pemanfaatan dan Perilaku Penggunaan Sistem Ekokardiografi, Jurnal Teknologi, 2013, volume 6(2), pages 169-178.

[20] Sargent, K, Hyland, P and Sawang, S, "Factors Influencing the Adoption of Information Technology in a Construction Business", Australasian Journal of Construction Economics and Building, volume 12(2), 2012, pages 72-86.
[21] Ajzen, I and Fishbein, M, “Attitude-Behavior Relations : A Theoretical Analysis and Review of Empirical Research”, Psychological Bulletin, volume 84(5), 1977, pages 888-918, 1977.

[22] Davis, F, D, "Perceived Usefulness, Perceived Ease of Use, and User Acceptance of Information Technology", MIS Quarterly,1989, volume 13(3), pages 319340.https://doi.org/10.2307/249008.

[23] Igbaria, M, Iivari, Jand Maragahh, H, "Why Do Individuals Use Computer Technology? A Finnish Case Study", volume 29, 1989, pages 227-238. https://doi.org/10.1016/0378-7206(95)00031-0.

[24] Ajzen, I, "The Theory of Planned Behavior", Organizational Behavior And Human Decision Processes, volume 50, 1991, pages 179-211.

[25] Taylor, S and Todd, P, A, "Understanding Information Technology Usage: A Test of Competing Models", Information Systems Research, volume 6(2), 1995, pages

144-176. https://doi.org/10.1002/9780470479216.corpsy0834

[26] Thompson, B, R, L, et al, "Personal Computing: Toward a Conceptual Model of Utilization", MIS Quarterly, March 1991, pages 125-143, https://doi.org/10.1.1.894.9540.

[27] Valente, W, T and Rogers, E, M, "The Origin and Development of the Diffusion of Innovations Paradigm as an Example of Scientific Growth", Science Communication, volume 16(3), March 1995, pages 242273,https://doi.org/10.1177/1075547095016003002.

[28] Hawkins, R, M, F, "Self-Efficacy: A Predictor But Not A Cause Of Behavior", J.Behav.Ther.\& Exp.Psychiat, volume 23(4), 1992, pages 251256,https://doi.org/10.1016/0005-7916(92)90047-m

[29] Ajzen, I, “Attitudes, Traits, And Actions : Dispositional Prediction Of Behavior In Personality And Social Psychology", Advances In Experimental Social Psychology, volume 20, 1987, pages 1-63, https://doi.org/10.1016/S0065-2601(08)60411-6.

[30] Lazzeri, F, "On Defining Behavior: Some Notes", Behavior and Philosophy, volume 42, 2014, pages 6582.

[31] Bergner, R, M, "New Ideas in Psychology What is behavior? And So what?," New Ideas Psychol., volume 29(2),2011, pages 147-155.

[32] Venkatesh, V, et al, "User Acceptance of Information Technology: Toward a Unified View', Management Information Systems Research Center, University of Minnesota, volume 27(3), 2011, pages 425-478.

[33] Venkatesh, V, et al, "Consumer Acceptance and Use of Information Technology:Extending the Unified Theory of Acceptance and Use of Technology", Forthcoming in MIS Quarterly, volume 36(1), 2012, pages 157-178.

[34] Ghalandari, K, "The Effect of Performance Expectancy, Effort Expectancy, Social Influence and Facilitating Conditions on Acceptance of E-Banking Services in Iran : the Moderating Role of Age and Gender", MiddleEast Journal of Scientific Research, volume 12(6),2012, pages https://doi:10.5829/idosi.mejsr.2012.12.6.2536.

[35] Maillet, E, Mathieu, Land Sicotte, C, "Modeling Factors Explaining the Acceptance, Actual Use and Satisfaction of Nurses Using an Electronic Patient Record in Acute Care Settings: An Extension of the UTAUT",Int. J. Med. Inform, volume 84(1), 2014, pages 36-47, http://dx.doi.org/10.1016/j.ijmedinf.

[36] Ojaide, F and OnyejiakaAgochukwu, B, "The Effect of Effort Expectancy on Computer-Assisted Audit TechniquesUsage by External Auditors in Nigeria", IJMSR, volume 3(1), 2016, pages 193-204.

[37] Venkatesh, V and Zhang, X, "Unified Theory of 
Acceptance and Use of Technology: US Vs China", Journal of Global Information Technology Management, volume 13(1), 2010, pages 5-27.

[38] Vannoy, S, A and Palvia, P, "The Social Influence Model of Technology Adoption", volume 53(6), ACM, June 2010, pages 149-153, http://dx.doi.org/10.1145/1743546.1743585.

[39] Fischer, R and Vauclair, C-M, "Social influence and power", A Psicologia Social Brasileira: Principais temas e vertentes, January2015, pages 1-35.

[40] Workman, M, "Computers in Human Behavior New Media and the Changing Face of Information Technology Use: The Importance of Task Pursuit, Social Influence, and Experience", Comput. Human Behav,volume 31, 2014, pages 111117.http://dx.doi.org/10.1016/j.chb.2013.10.008.

[41] Goldsmith, E. B, "Social Influence History and Theories", Social Influence and Sustainable Consumption, 2015, pages 2340,http://dx.doi.org/10.1007/978-3-319-20738-4_2.

[42] Lai, PC, "The Literature Review of Technology Adoption Models and Theories for the Novelty Technology", JISTEM - Journal of Information Systems and Technology Management, volume 14(1), Jan/Apr., 2017, pages 21-38, http://dx.doi.org/10.4301/S180717752017000100002 .

[43] Venkatesh, V, Davis, F. Dand Davis, F, “A Theoretical Extension of the Technology Acceptance Model: Four Longitudinal", Management Science, volume 46 (2), 2000, pages 186-204, http://dx.doi.org/10.1287/mnsc.46.2.186.11926.

[44] Venkatesh, V, Morris, M. G. and Ackerman, P. L, “A Longitudinal Field Investigation of Gender Differences in Individual Technology Adoption Decision-Making Processes", Organizational Behavior and Human Decision Processes, volume 83(1), 2000, pages 3360.http://dx.doi.org/10.1006/obhd.2000.2896.

\section{BIODATA PENULIS}

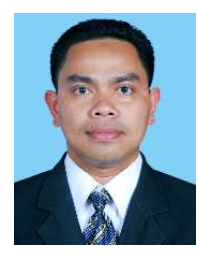

Krismadinata

Penulis adalah Dosen Tetap Jurusan Teknik Elektro Fakultas Teknik Universitas Negeri Padang sejak tahun 2000. Penulis menyelesaikan studi S1 di Universitas Andalas tahun 2000; S2 di Institut Teknologi Bandung tahun 2004; S3 di University of Malaya 2012.

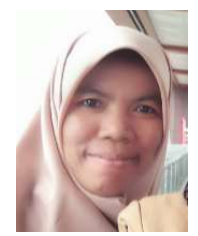

Yezi Arnovia

Penulis saat ini bekerja sebagai Aparatur Sipil Negara di Dinas Perdagangan, Koperasi dan UKM Pemerintah Kota Solok Propinsi Sumatera Barat.

Menyelesaikan studi S1 di Fakultas Teknik, Jurusan Teknik Industri, Universitas Andalas tahun 2000; S2 di Fakultas Teknik, Pendidikan Teknologi dan Kejuruan dengan konsentrasi Chief Information Officer (CIO), Universitas Negeri Padang tahun 2016.

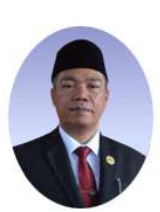

Syahril

Penulis adalah Dosen Tetap Jurusan Teknik Mesin, Fakultas Teknik, Teknik Universitas Negeri Padang sejak tahun 1988 sampai sekarang. Penulis menyelesaikan studi S1 di IKIP Jurusan PT Mesin Tahun 1988; S2 di Universitas Gajah Mada Jogjakarta; S3 di Universiti Kebangsaan Malaysia tahun 2011.

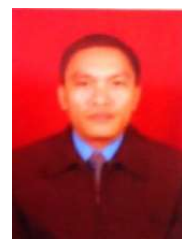

Yahfizham

Penulis adalah Dosen Tetap pada Universitas Islam Negeri Sumatera Utara Medan sejak tahun 2005 sampai sekarang. Menyelesaikan studi S1 di Sekolah Tinggi Teknik Harapan (STTH) Medan tahun 2004; S2 Universitas Gajah Mada Jogjakarta (UGM) tahun 2010. Saat ini sebagai mahasiswa aktif Program Doktor, Fakultas Teknik, Program Studi Pendidikan Teknologi dan Kejuruan, Universitas Negeri Padang. 
